\title{
MARAH DAN KUALITAS HIDUP ORANG YANG MENGALAMI PSIKOSOMATIK
}

\author{
Witrin Gamayanti, Ila Nurlaila Hidayat \\ Fakultas Psikologi, UIN Sunan Gunung Djati Bandung \\ Jalan A. H. Nasution No. 105 Cibiru Bandung Indonesia 40614 \\ witrin.gamayanti@uinsgd.ac.id
}

\begin{abstract}
This study aims to determine the correlation of anger to the quality of life of people who experience psychosomatic. Negative emotions may cause psychosomatic disorders, including anger. These emotions affect the neurological working mechanism that activates an excessive number of neural, neuroendocrine and endocrine and attack the individual's weakest organs. By using non-probability sampling of purposive sampling type, the research was conducted on 106 college students of UIN Sunan Gunung Djati Bandung who experienced the psychosomatic disorder, based on the screening result of inventory to detect the psychosomatic disorder. The data were obtained through two scales: State-Trait Anger Expression Inventory-2 (STAXI-2) (51 items; $\alpha=.819)$, and the quality of life scale of WHO that has been adapted ( 52 items; $\alpha=.863$ ). The data were analyzed with simple linear regression test. The results show that anger has a significant correlation to the quality of life of people who experience psychosomatic, $F(1,104)=$ $6.063 ; p=.015$. As the anger getting higher, quality of life on an individual who experiences psychosomatic would be getting lower, $\beta=-.235 ; p=.015$.
\end{abstract}

Keywords: anger; quality of life; psychosomatic

\begin{abstract}
Abstrak
Penelitian ini bertujuan untuk mengetahui korelasi marah dengan kualitas hidup orang yang mengalami psikosomatik. Emosi negatif yang menyebabkan gangguan psikosomatik di antaranya adalah marah. Emosi ini mempengaruhi mekanisme kerja neurologis sehingga mengaktifkan sejumlah neural, neuroendocrine dan endocrine yang berlebihan dan menyerang organ terlemah individu. Dengan menggunakan non-probability sampling jenis purposive sampling, penelitian dilakukan terhadap 106 mahasiswa yang mengalami gangguan psikosomatik, berdasarkan hasil screening berupa inventory untuk mendeteksi gangguan psikosomatik. Data diperoleh melalui dua skala yaitu State-Trait Anger Expression Inventory-2 (STAXI-2) (51 item; $\alpha=0,819)$, dan skala kualitas hidup dari WHO yang telah diadaptasi (52 item; $\alpha=0,863)$. Analisis data menggunakan uji regresi linier sederhana. Diperoleh hasil bahwa marah memiliki peran signifikan dengan kualitas hidup orang yang mengalami psikosomatik, $F(1,104)=6,063 ; p=0,015$. Semakin tinggi marah maka semakin rendah kualitas hidup orang yang mengalami psikosomatik, $\beta=-0,235 ; p=0,015$.
\end{abstract}

Kata kunci: marah; dengki; bersyukur; kualitas hidup; psikosomatik

\section{PENDAHULUAN}

Data yang diungkap oleh World Health Report (2001) bahwa lebih dari 450 juta orang di dunia ini mengalami gangguan mental, jumlah ini tidak sebanding dengan orang-orang yang telah ditangani oleh tenaga profesional seperti psikolog dan psikiater. Menurut penelitian yang dilakukan WHO di beberapa negara berkembang, menunjukkan bahwa 30-50\% yang berobat ke pusat layanan kesehatan umum menderita gangguan jiwa.

Berdasarkan Riset Kesehatan Dasar tahun 2018 , angka prevalensi penduduk berusia $\geq 15$ tahun yang mengalami gangguan mental emosional meningkat sebesar 9,8\% dibandingkan sebelumnya sebesar 6\% (pada tahun 2013) dari seluruh penduduk Indonesia (Kementerian Kesehatan Republik Indonesia, 2018). Data 
yang diperoleh di lapangan (Kabupaten Sleman Daerah Istimewa Yogyakarta), hasil rekapitulasi data keluhan pasien di Pemeriksaan Umum yang dirujuk ke Psikolog Puskesmas, kebanyakan pasien yang datang ke pelayanan primer, mengeluhkan berbagai gejala yang tidak jelas dan sering kali terkait dengan kondisi fisiknya (Retnowati, 2011). Melihat semua informasi ini, bisa jadi orang yang mengalami gangguan kesehatan mental dengan keluhan fisik bisa bertambah, mengingat puskesmas di Indonesia sangat banyak dan menyebar di seluruh Indonesia. Dengan kata lain di Indonesia cukup banyak orang yang mengalami sakit fisik yang penyebabnya adalah masalah psikologis dalam hal ini adalah masalah emosi. Data terbaru menunjukkan dari 181 orang yang menghadiri Layanan Kesehatan Jiwa Bergerak (Mobile Mental Health Services/MMHS), sebanyak $49 \%$ mengalami masalah kesehatan jiwa (http://www.depkes.go.id).

Diperkirakan bahwa lebih dari 90\% kunjungan pasien ke dokter disebabkan oleh masalah kesehatan yang sebagiannya dipengaruhi oleh stres. Dengan demikian gangguan psikosomatik merupakan hal yang sebenarnya telah umum terjadi namun sering kali tidak disadari (Scott, 2018).

Masalah emosional yang tidak tertangani dapat menjadi penyebab penyakit fisik, karenanya banyak sekali pengobatan penyakit fisik tidak membuahkan hasil optimal karena mengabaikan masalah emosional tersebut. Karena intervensi medis sering kali tidak dapat menyembuhkan penyakit sepenuhnya, maka dalam hal ini dibutuhkan pendekatan lainnya untuk mengatasi penyakit kronis, termasuk intervensi psikologis. Psikoterapi dibutuhkan terutama menekankan pada peningkatan fungsi fisik, emosional, sosial, serta pekerjaan dibandingkan dengan hanya berfokus pada penyembuhan penyakit itu sendiri (Sturgeon, 2014). Pendekatan psikologis tidak boleh dipandang hanya sebagai alternatif melainkan harus diintegrasikan sebagai bagian dari pendekatan komprehensif untuk pengobatan pasien dengan penyakit neuropatik kronis (Turk, Audette, Levy, Mackey, \& Stanos, 2010).

Gangguan psikosomatik adalah gangguan fisik (sakit fisik) yang penyebab atau kekambuhannya diperparah oleh kondisi psikologis, misalnya karena stres atau tekanan emosional (Everly \& Lating, 2002). Stres atau permasalahan emosional bisa menjadi stresor bagi tubuh, dan akan "menyerang" organ terlemah dari seseorang. Organ tubuh menjadi lemah bisa jadi karena adanya faktor herediter, atau karena gaya hidup yang tidak sehat, karenanya mengobati gangguan ini tidak bisa hanya dengan layanan medis saja tetapi juga melibatkan pendekatan psikologis. Gangguan yang termasuk ke dalam psikosomatik yaitu gangguan gastrointestinal, gangguan pada jantung dan pembuluh darah (cardiovascular), allergy, bronchial asthma, gangguan musculoskeletal dan gangguan kulit (Everly \& Lating, 2002). Adapun menurut Carson \& Butcher (1992), penyakit diabetes juga tergolong psikosomatik.

Emosi positif, hubungan sosial yang positif serta kesehatan fisik saling mempengaruhi secara dinamis, dengan kata lain emosi positif dapat meningkatkan persepsi mengenai hubungan sosial yang positif pula, yang pada gilirannya hal ini dapat meningkatkan kesehatan fisik (Kok dkk., 2013). Berbeda halnya dengan orang-orang yang mengalami gangguan psikosomatik, menurut Everly \& Lating (2002) emosi yang sering muncul pada mereka adalah marah dan rage (sangat marah/murka). Pada gangguan maag, marah, agresi atau kebencian yang ia tekan atau tidak bisa dikelola dengan baik akan memancing lambung untuk memproduksi asam lambung dan pepsin yang berlebihan dan ini membuat lambung iritasi dan perih, sakit atau kembung. 
Pada kasus radang usus, emosi marah dan resentment (kecewa berat dan cenderung dipendam/tidak bisa diungkapkan dengan jelas). Untuk gangguan cardiovascular, kondisi emosi yang sering kali muncul adalah kecemasan, kebencian, resentment, agresi, depresi, dan keinginan untuk segera menyingkirkan masalah (wish to be rid of trouble). Kondisi psikologis yang sering memancing gangguan pernafasan adalah cemas, ketakutan dan kebencian. Apabila melihat kondisi emosi atau psikologis yang dialami oleh gangguan musculoskeletal adalah marah dan cemas yang membuat otot menjadi berkontraksi dan menimbulkan tekanan pada sakit kepala (Everly \& Lating, 2002).

Kesehatan fisik dan mental merupakan dua hal yang sangat berkaitan erat. Ditemukan bahwa kesehatan mental (fisik) di masa lalu memiliki dampak langsung dan tidak langsung yang signifikan terhadap kesehatan fisik (mental) saat ini (Ohrnbergera, Ficherab, \& Suttona, 2017).

Bagaimana kondisi psikologis mempengaruhi kesehatan fisik? Menurut Everly dan Lating (2002) yaitu melalui pemaknaan terhadap masalah yang dihadapi. Pemaknaan terhadap situasi memunculkan emosi negatif misalnya marah (angry), kebencian (hostility), rage, resentment, sedih, depresi, merasa tidak mampu (inferior), cemas (anxiety) dan emosi negatif lainnya, ternyata kemunculan emosi ini bisa menyebabkan stres pada sistem neurologi yang kemudian membuat mekanisme neural, neuroendokrin dan endokrin bekerja tidak sebagaimana mestinya yang bisa berakibat fatal pada kesehatan, bahkan bisa berdampak pada kematian.

Marah menurut Spielberger dan Reheiser (2009) adalah kondisi emosi dari perasaan yang intensitasnya bervariasi dari mudah terganggu dalam level ringan (mild irritation) sampai marah luar biasa (fury and rage). Marah sendiri terbagi ke dalam dua yaitu trait anger dan state anger.

Adapun kualitas hidup/quality of life (QoL) menurut WHO (World Health Organization) adalah penilaian individu terhadap posisi individu dalam hidup berkaitan dengan konteks budaya dan sistem nilai di mana mereka berada serta berkaitan juga dengan tujuan, harapan, standar serta fokus perhatian mereka. Menurut WHO terdapat enam dimensi yaitu physical health, psychological, level independence, social relationship, environment, spirituality/ religion atau personal belief. Keenam dimensi tersebut kemudian diringkas menjadi empat domain yaitu, fisik, psikologis, relasi sosial dan lingkungan (WHO, 1997). Konsep QoL menurut WHO pada akhirnya menggabungkan domain spiritual ke dalam domain psikologis.

Penelitian terdahulu membuktikan bahwa masalah emosi mempengaruhi kualitas hidup orang-orang yang mengalami psikosomatik (Zboralski dkk., 2008). Penelitian ini juga menjelaskan bahwa kualitas hidup orang yang memiliki gangguan psikosomatik lebih rendah dibandingkan dengan orang yang sehat.

Penelitian lain yang dilakukan oleh White, Hopkins, Glissmeyer, Kitterman, \& Elliott (2006) menyebutkan bahwa orang dengan pulmonary arterial hypertension, secara kognitif terganggu, depresi, cemas dan kualitas hidupnya menurun. Selanjutnya penelitian yang dilakukan di Iran mengenai orang yang mengalami gangguan peptic ulcer atau gangguan maag bahwa ketika seseorang mengalami gangguan ini akan menurunkan kualitas hidupnya, karenanya penting untuk mencegah atau mengobati gangguan supaya bisa meningkatkan kualitas hidup mereka (Hafez, Tavassoli, Hasanzadeh, Reisi, Javadzade, \& Imanzad, 2013).

Beberapa penelitian yang sudah dilakukan hanya menghubungkan antara satu jenis 
gangguan psikosomatik dengan kualitas hidup, misalnya penelitian kualitas hidup pada orang yang mengalami urticarial (Silvares, Fortes \& Miot, 2011), kualitas hidup pada orang yang mengalami gangguan peptic ulcerl gangguan maag (Hafez dkk., 2013). Dalam penelitian ini peneliti tidak membatasi jenis gangguan psikosomatiknya karena asumsinya penyebab semua gangguan psikosomatik salah satunya adalah emosi marah dan ingin melihat seberapa besar pengaruh marah tersebut terhadap kualitas hidup orang yang mengalami psikosomatik.

Berdasarkan hasil penelitian yang telah diuraikan di atas, dapat dilihat bahwa penyebab orang mengalami psikosomatik adalah emosi negatif yang menjadi stresor bagi organ terlemah, meskipun tidak diuraikan secara spesifik emosi apa yang dimaksud, hasil penelitian lainnya menyebutkan orang yang psikosomatik kualitas hidupnya menurun. Hasil penelitian tersebut dijelaskan secara terpisah dalam penelitian yang berbeda. Dalam penelitian ini, peneliti menelusuri peran emosi marah terhadap kualitas hidup pada orang yang mengalami psikosomatik.

\section{METODE}

Penelitian ini menggunakan pendekatan kuantitatif, dengan metode korelasional jenis causal correlation. Dengan analisis regresi linier sederhana, penelitian ini menguji korelasi peran variabel independen yaitu marah terhadap satu variabel dependen yaitu kualitas hidup.

Variabel marah diukur dengan menggunakan skala yang diadaptasi ke dalam Bahasa Indonesia dari State-Trait Anger Expression Inventory-2 (STAXI-2). Skala ini dibuat oleh Vagg dan Spielberger (2000) sebagai pengembangan terhadap State-Trait Anger Expression Inventory (STAXI) yang telah dibuat sebelumnya yaitu pada tahun 1988 .
Skala terdiri dari 57 item yang meliputi tiga aspek yaitu trait anger, state anger, serta anger expression dan anger control. Hasil uji coba menunjukkan terdapat 43 item terpakai, 6 item dihapus, serta 8 item yang dapat diperbaiki. Dengan demikian pada pengambilan data hanya digunakan 51 item dengan terlebih dahulu melakukan revisi pada 8 item, yang mana kedelapan item tersebut terdapat pada dimensi anger expression and anger control.

Variabel Kualitas Hidup (Quality of Life) diukur dengan menggunakan skala kualitas hidup yang dibuat oleh WHO, dan dikembangkan oleh peneliti dengan memunculkan kembali aspek spiritual atau religiositas sehingga terdiri dari 5 aspek yaitu fisik, psikologis, relasi sosial, lingkungan, dan spiritual. Skala ini berisi 71 item. Hasil uji coba menunjukkan terdapat 49 item terpakai, 3 item dihapus, serta 19 item yang dapat diperbaiki. Dengan demikian pada pengambilan data hanya digunakan 52 item yang diambil dari 46 item terpakai dan 6 item yang telah diperbaiki. Jumlah tersebut diperoleh dengan memperhatikan keseimbangan sebaran item pada setiap aspek maupun indikator.

Hasil pengujian validitas konstruk menggunakan uji korelasi Pearson Product-moment menunjukkan bahwa kedua skala merupakan alat ukur yang tergolong valid atau tepat dalam mengukur fungsi ukurnya masing-masing. Dapat dilihat pada tabel 1 kisaran nilai korelasi antara 0,443-0,758. Meskipun pada skala marah terdapat salah satu aspek yang memiliki nilai korelasi lebih rendah, namun kesimpulan mengenai validitas alat ukur secara utuh masih dapat diwakili oleh aspek-aspek lain di dalamnya. Selanjutnya perhitungan uji reliabilitas pun menunjukkan hasil bahwa kedua skala tergolong reliabel dengan kisaran nilai koefisien alpha sebesar 0,819 dan 0,863.

Subjek penelitian adalah mahasiswa UIN Sunan Gunung Djati Bandung yang mengalami 
gangguan psikosomatik. Terkait karakteristik khusus tersebut, teknik pengambilan sampel dalam penelitian ini menggunakan nonprobability sampling dengan jenis purposive sampling. Dalam hal ini peneliti melakukan screening dengan inventory untuk mendeteksi gangguan psikosomatik. Berdasarkan lembar screening yang diberikan kepada mahasiswa sebanyak 230 orang, diperoleh hasil bahwa terdapat 106 mahasiswa yang dapat dikategorikan sebagai individu yang mengalami gangguan psikosomatik.

Tabel 1. Hasil Uji Validitas

\begin{tabular}{lc}
\hline \multicolumn{1}{c}{ Skala/Dimensi } & $\begin{array}{c}\text { Nilai } \\
\text { Korelasi }\end{array}$ \\
\hline Marah & \\
Trait Anger (T-Ang) & 0,634 \\
State Anger (S-Ang) & 0,443 \\
Anger Expression \& Anger Control & 0,758 \\
Kualitas Hidup & \\
Kualitas hidup secara umum & 0,599 \\
Kesehatan secara umum & 0,599 \\
Physical & 0,557 \\
Psychological & 0,736 \\
Social Relationship & 0,626 \\
Environment & 0,728 \\
Spirituality/Religiosity & 0,618 \\
\hline
\end{tabular}

Untuk menganalisis data, peneliti menggunakan teknik analisis statistik deskriptif dan teknik analisis inferensial. Untuk memperoleh gambaran karakteristik subjek penelitian digunakan analisis statistik deskriptif dengan membuat kategorisasi ke dalam tiga tingkatan yaitu rendah, sedang, tinggi berdasarkan nilai mean dan standar deviasi pada setiap variabel. Adapun untuk menguji hipotesis digunakan teknik analisis inferensial dalam pengambilan keputusan. Teknik analisis inferensial yang digunakan adalah analisis regresi linier sederhana. Analisis data dilakukan dengan bantuan perangkat lunak SPSS versi 20.

\section{HASIL DAN PEMBAHASAN}

Berdasarkan hasil uji $F$, didapatkan nilai $F$ hitung sebesar 6,063 dengan angka signifikansi
( $\left.P_{\text {Value }}\right)$ 0,015. Dengan tingkat kepercayaan 95\% $(\alpha=0,05)$, dapat dilihat bahwa nilai $P_{\text {Value }}$ lebih kecil dari alpha $(0,015<0,05)$. Berdasarkan perbandingan tersebut dapat disimpulkan bahwa model regresi dalam penelitian ini sudah layak digunakan untuk memprediksi variabel dependen kualitas hidup. Dengan kata lain variabel independen marah (X) memiliki korelasi signifikan dengan variabel dependen kualitas hidup (Y).

Adapun nilai $R$ Square adalah sebesar 0,055. Hasil tersebut dapat diartikan bahwa variabel independen (marah) dapat menjelaskan variabel dependen (kualitas hidup) sebesar 5,5\%, sedangkan sisanya sebesar 95,4\% variabel kualitas hidup dapat dijelaskan oleh variabel lainnya yang tidak diteliti dalam penelitian ini.

Analisis regresi menghasilkan persamaan regresi linier sederhana $(Y=213,410+-$ 0,237X). Berdasarkan hasil perhitungan tersebut, terbukti bahwa marah berkorelasi negatif secara signifikan dengan kualitas hidup pada orang yang mengalami psikosomatik. Hal ini dapat ditunjukkan dari nilai signifikansi yang bernilai 0,015 lebih kecil dari alpha $(0,015<0,05)$. Nilai koefisien regresi $(\beta)$ yang bernilai negatif sebesar $-0,237$, artinya setiap peningkatan variabel marah sebesar 1 angka maka variabel kualitas hidup pada orang yang mengalami psikosomatik akan berkurang sebesar 0,237. Sehingga dapat dikatakan bahwa semakin tinggi tingkat marah individu, maka kualitas hidupnya akan menurun.

Melihat hasil perhitungan statistik diperoleh informasi bahwa nilai konstanta dari variabel marah sebesar 213,410 artinya jika variabel marah nilainya 0 maka variabel kualitas hidup memiliki nilai positif sebesar 213,410. Variabel marah memiliki korelasi signifikan dengan kualitas hidup orang yang mengalami psikosomatik $(0,015<0,05)$ artinya semakin tinggi marah yang dialami seseorang maka 
semakin tidak berkualitas hidup orang yang memiliki gangguan psikosomatik.

Untuk variabel marah, ketika orang semakin pemarah maka kehidupannya semakin tidak bahagia dan tidak mengalami kepuasan dalam berbagai aspek. Penelitian ini membuktikan bahwa marah hanya akan menimbulkan kegelisahan yang memunculkan rasa tidak tenang dalam menjalani hidup (Everly \& Lating, 2002). Semakin tinggi tingkat marah seseorang semakin hidupnya tidak berkualitas. Orang yang mengalami psikosomatik adalah orang yang memiliki emosi marah yang dominan, dan dalam penelitian ini rata-rata orang psikosomatik memiliki tingkat marah yang sedang $(68,82 \%)$. Ini juga membuktikan bahwa marah cukup berperan besar dalam kemunculan psikosomatik. Dalam beberapa penelitian, sudah dibuktikan bahwa kualitas hidup seseorang berkurang ketika ia mengalami psikosomatik tanpa dijelaskan alasannya, dalam penelitian ini dibuktikan bahwa peran marah ternyata menjadi penyebab mengapa orang dengan psikosomatik menjadi rendah kualitas hidupnya. Dampak marah bukan hanya sebatas ia memaki-maki atau mengekspresikan kemarahan dengan agresi tetapi merusak banyak hal di antaranya kejernihan berpikir, melihat segala sesuatu dengan objektif dan kemampuan dalam mengambil keputusan menjadi berkurang, sebagai dampaknya kemungkinan untuk salah dalam memersepsi sesuatu dan tidak tepat dalam mengambil tindakan menjadi besar. Secara sosial pun akan merusak relasinya dengan banyak pihak dan untuk jangka panjang ini juga akan mengganggu kondisi emosi orang yang bersangkutan. Seperti sudah dijelaskan sebelumnya bahwa emosi marah itu muncul karena persepsi kita yang negatif terhadap masalah dan memancing emosi marah yang menyebabkan stres pada sistem neurologi yang kemudian membuat mekanisme neural, neuroendokrin dan endokrin bekerja tidak sebagaimana mestinya yang bisa berakibat fatal pada kesehatan, bahkan bisa berdampak pada kematian (Everly \& Lating, 2002). Cara kerja yang salah dalam sistem neurologi ini menyerang organ terlemah yang membuat seseorang mengalami psikosomatik. Bisa dipahami ketika seseorang marah maka selain penyakitnya berulang kambuh hal ini berdampak pada kualitas hidup yang menurun.

Hasil penelitian ini sejalan dengan beberapa penelitian lainnya pada berbagai kelompok subjek yang mengalami gangguan kesehatan baik secara fisik maupun mental yaitu pada pasien dengan penggunaan alkohol berlebihan atau riwayat penggunaan narkoba suntikan (Marcellin dkk., 2017; Sharma, Suman, Pratima Murthy, \& Marimuthu, 2012); pasien multiple sclerosis (Laing, Phillips, Cooper, Hosie, \& Summers, 2015); ataupun pasien kanker (Barinková, \& Mesarosova, 2013). Penelitianpenelitian tersebut pada dasarnya menegaskan bahwa marah secara signifikan berkaitan dengan kualitas hidup. Kualitas hidup yang merupakan penilaian individu berkaitan dengan harapan ataupun standar dalam berbagai aspek kehidupannya meliputi kesehatan fisik, psikologis, level independensi, relasi sosial, lingkungan serta keyakinan personal, tentunya dapat rentan terganggu ketika individu dikuasai oleh emosi negatif berupa marah. Kemarahan memiliki konsekuensi negatif baik secara fisiologis dan psikologis untuk individu, namun ini bisa menjadi risiko yang lebih besar dalam populasi klinis di mana perasaan marah mungkin dirasakan lebih tinggi dibandingkan dengan populasi non-klinis (Laing dkk., 2014). Dengan demikian temuan penelitian ini memperkuat bahwa pada populasi klinis berupa gangguan psikosomatik, emosi marah masih berperan bagi rendahnya kualitas hidup mereka. Artinya berbagai aspek dalam kehidupan mereka dirasakan menjadi kurang memuaskan disebabkan mereka cenderung bereaksi marah ketika mendapat kritik, baik kemarahan itu diekspresikan secara verbal maupun fisik, ataupun ditekan ke dalam dirinya sendiri. 
Dalam penelitian ini belum secara spesifik menelusuri bagaimana keterkaitan antara setiap dimensi marah dengan dimensi kualitas hidup. Penelitian lain melaporkan bahwa dimensi anger expression-in (kecenderungan untuk menangani kemarahan dengan menjaganya tetap di dalam) secara independen memprediksi kualitas hidup yang lebih buruk pada pasien multiple sclerosis yang dimoderasi oleh jenis kelamin, menunjukkan bahwa anger expression-in adalah prediktor yang lebih berpengaruh terhadap kualitas hidup pada penderita multiple sclerosis wanita (LabianoFontcuberta, Mitchell, \& Moreno-García, 2015).

Penelitian lain mengenai anger-expression menunjukkan bahwa anger-out berpengaruh negatif terhadap kualitas hidup pasien kanker wanita dibandingkan pria. Tidak sebatas kemarahan yang dialami pasien sendiri, terbukti pula bahwa anger-out dari pasangan juga turut berperan bagi kualitas hidup pasien, mengingat dukungan dari pasangan menjadi mediator penting yang menghubungkan antara angerexpression dan kualitas hidup. Arah hubungan yang ditemukan ternyata berbeda, yaitu pada pasien pria, level anger-out yang tinggi pada istrinya berhubungan positif dengan kualitas hidup mereka. Sebaliknya pada pasien wanita, level anger-out yang tinggi pada suaminya berhubungan negatif dengan kualitas hidup mereka (Julkunen, Gustavsson-Lilius, \& Hietanen, 2009).

Julkunen, Gustavsson-Lilius, dan Hietanen, (2009) menunjukkan bahwa skor marah yang rendah adalah normal dan yang lebih penting adalah kualitas marah yang diungkapkan pasien, yang berarti ekspresi marah (angerexpression) dan pengendalian marah (angercontrol) positif untuk meningkatkan kualitas hidup, sedangkan penghambatan marah (angerinhibition) dapat menurunkan kualitas hidup. Penelitian lain menemukan bahwa orang yang menginternalisasi atau menekan kemarahan, mereka memiliki kualitas hidup yang berhubungan dengan kesehatan yang lebih buruk (ini terutama berlaku untuk wanita). Di sisi lain, sifat marah (trait-anger) tidak memprediksi kualitas hidup terkait kesehatan yang lebih buruk. Ini menunjukkan bahwa bukan kemarahan itu sendiri yang mempengaruhi kepuasan hidup seseorang, tetapi apakah mereka menyimpan perasaan marah itu untuk diri mereka sendiri (LabianoFontcuberta, Mitchell, \& Moreno-García, 2015). Penelitian lainnya menyatakan terdapat korelasi signifikan antara kualitas hidup dan trait-anger serta anger-in pada remaja yang mengalami gangguan kesehatan kulit berupa jerawat (Kum, Erturan, \& Aktepe, 2014).

Berbagai penelitian di atas termasuk juga penelitian ini, pada prinsipnya menegaskan satu temuan yang sama bahwa secara umum, emosi negatif berupa marah berkaitan signifikan dengan kualitas hidup seseorang. Adapun secara spesifik bagaimana setiap dimensi marah yang meliputi state-anger, trait-anger, anger expression and control berkaitan dengan kualitas hidup, tampaknya masih menunjukkan kecenderungan yang berbeda-beda pada berbagai karakteristik subjek, tergantung pada jenis gangguan kesehatan serta dampak psikologis lain yang turut menyertai. Penelitian ini sendiri memberikan kontribusi terkait hubungan marah dan kualitas hidup khususnya pada individu yang mengalami psikosomatik. Dengan demikian dapat dijelaskan bahwa perbedaan dengan penelitian lainnya terletak pada karakteristik subjek, yang mana penelitian lain umumnya meneliti subjek yang mengalami gangguan fisik sebenarnya, sedangkan dalam penelitian ini menekankan pada penderita keluhan fisik yang bukan sebenarnya, karena keluhan fisik tersebut merupakan sebuah mekanisme yang distimulasi oleh faktor psikologis. Hal ini dapat berarti bahwa dimungkinkan faktor-faktor yang menjadi penyebab marah merupakan hal yang berbeda. 


\section{SIMPULAN}

Hasil penelitian menunjukkan bahwa variabel marah memiliki peran negatif yang signifikan dengan kualitas hidup orang yang mengalami gangguan psikosomatik, yang berarti semakin tinggi level marah orang yang mengalami psikosomatik maka menjadi semakin rendah kualitas hidupnya. Saran bagi penelitian selanjutnya, mengingat dalam penelitian ini baru digali satu jenis emosi negatif yang berkorelasi dengan kualitas hidup orang yang mengalami psikosomatik, ada baiknya diteliti lebih lanjut emosi-emosi lain supaya dapat menentukan emosi yang paling tinggi korelasinya dengan psikosomatik baik emosi positif maupun negatif.

\section{DAFTAR PUSTAKA}

Carson, C. R., \& Butcher, J. (1992). Abnormal psychology and modern life (9th Ed.). New York, NY: HarperCollins Publishers Inc.

Chibnall, J. T., \& Tait, R. C. (2015). The psychosomatic symptom checklist revisited: Reliability and validity in a chronic pain population. Journal of Behavioral Medicine, 12(3), 297-307. doi: 10.1007/BF00844873.

Compton, W. C. (2005). Introduction to positive psychology. Belmont, CA: Thomson/ Wadsworth.

De Azevedo, F. B., Wang, Y. P., Goulart, A. C., Lotufo, P. A., \& Bensenor, I. M. (2010). Application of the spielberger's state-trait anger expression inventory in clinical patients. Arq Neuropsiquiatr, 68(2), 231234.

Diener, E., Lucas, R.E., \& Oishi, S. (2005). Subjective well-being: The science of happiness and life satisfaction. In S. J. Lopez, C. R. Snyder, The Oxford
Handbook of Positive Psychology. New York, NY: Oxford University Press.

Dunn, D. S. (2017). Positive psychology: Established and emerging issues. New York, NY: Routledge Taylor \& Francis Group.

Everly, G. S. Jr., \& Lating, J. M. (2002). A clinical guide to the treatment of the human stress response (2nd Ed.). New York, NY: Kluwer Academic Publishers.

Hafez, A. A., Tavassoli, E., Hasanzadeh, A., Reisi, M., Javadzade, S. H., \& Imanzad, M. (2013). Quality of life in peptic ulcer patients referring to Al-Zahra Hospital of Isfahan Iran. Gastroenterology and Hepatology from Bed to Bench, 2013(6), S87-S92.

Julkunen, J., Gustavsson-Lilius, M., \& Hietanen, P. (2009). Anger expression, partner support, and quality of life in cancer patients. Journal of Psychosomatic Research, 66(3), 235244. doi: 10.1016/j.jpsychores.2008.09.011.

Kementerian Kesehatan Republik Indonesia. (2018). Hasil Utama Riskedas 2018 (Balitbangkes No. 071118). Diunduh dari http://dinus.ac.id/repository/docs/ajar/ha sil-riskesdas-2018.pdf

Kementerian Kesehatan Republik Indonesia. (2019). Layanan kesehatan jiwa bergerak ramaikan pameran rakerkesnas. Diakses dari http://www.depkes.go.id pada 23 Februari 2019.

Kok, B. E., Coffey, K. A., Cohn, M. A., Catalino, L. I., Vacharkulksemsuk, T., Algoe, S. B., Brantley, M., \& Fredrickson, B. L. (2013). How positive emotions build physical health: Perceived positive social connections account for 
the upward spiral between positive emotions and vagal tone. Psychological Science, 24(7), 1123-1132. doi: $10.1177 / 0956797612470827$.

Kum, O., Erturan, I., \& Aktepe, E. (2014). The evaluation of quality of life, self-esteem, peer relationship and anger levels in adolescents with acne at an university hospital: A case control study. Anadolu Psikiyatri Derg., 15(2), 150-156. doi: 10.5455/apd.43505.

Labiano-Fontcuberta, A., Mitchell, A. J., \& Moreno-García, S. (2015). Impact of anger on the health-related quality of life of multiple sclerosis patients. Multiple Sclerosis, 21(5), 630-641. doi: $10.1177 / 1352458514549399$.

Laing, C. M., Phillips, L. H., Cooper, C. L., Hosie, J. A., Summers, M. (2015). Anger, quality of life and mood in multiple sclerosis. J Mult Scler 2, 1-6. DOI: http://dx.doi.org/10.4172/2376-03891000127

Marcellin, F., Protopopescu, C., Esterle, L., Wittkop, L., Piroth, L., Aumaitre, H., ... Carrieri, M. P. (2017). Short article: Anger and quality of life in patients coinfected with HIV and hepatitis $C$ virus: A cross-sectional study (ANRS CO13HEPAVIH). European Journal of Gastroenterol Hepatol, 29(7), 786-791. doi: 10.1097/MEG.0000000000000883.

Ohrnbergera, J., Ficherab, E., \& Suttona, M. (2017). The relationship between physical and mental health: A mediation analysis. Social Science \& Medicine, 195(2017), 42-49.

Barinková, K., \& Mesarosova, M. (2013). Anger, coping, and quality of life in female cancer patients. Social Behavior and Personality: An International Journal, 41(1), 135-142.

Retnowati, S. Psikolog Puskesmas: Kebutuhan dan tantangan bagi profesi Psikolog Klinis Indonesia. Orasi ilmiah, Fakultas Psikologi, Universitas Gadjah Mada, disampaikan pada 12 September 2011.

Scott, E. (2018). How to handle a stress-related psychosomatic illness. Diakses dari https://www.verywellmind.com/how-tohandle-psychosomatic-illness-3145090 pada 23 Februari 2019.

Sharma, K., Suman, L. N., Pratima Murthy, P., \& Marimuthu, P. (2012). Relationship of trait anger with quality of life and anger control among alcohol users Manoj. Open Journal of Psychiatry, 2012(2), 249-252. doi: 10.4236/ojpsych.2012.24033

Silvares, M. R. C., Fortes, M. R. P., \& Miot, H. A. (2011). Quality of life in chronic urticaria: A survey at Public University Outpatient Clinic, Botucatu (Brazil). Rev Assoc Med Bras, 57(5), 565-569.

Spielberger, C. D., \& Reheiser, E. C. 2009. Assessment of emotions: Anxiety, anger, depression, and curiosity. Applied Psychology: Health and Well-Being, 1(3), 271-302. doi:10.1111/j.17580854.2009.01017.x

Sturgeon, J. A. (2014). Psychological therapies for the management of chronic pain. Psychology Research and Behavior Management, 10(7), 115-24. doi: 10.2147/PRBM.S44762.

Turk, D. C., Audette, J., Levy, R. M., Mackey, S. C., \& Stanos, S. (2010). Assessment and treatment of psychosocial comorbidities in patients with neuropathic pain. Mayo Clinic 
Proceedings, $85(3$ Suppl), S42-S50. World Health Organization, Division of Mental doi: $10.4065 / \mathrm{mcp} .2009 .0648$

Vagg, P. R., \& Spielberger, C. D. (2000). Statetrait anger expression inventory ${ }^{\text {tm }}$ interpretive report (Research Report No. 123-45-6789). Diambil dari http://www4.parinc.com/webuploads/sa mplerpts/staxi2_ir.pdf

White, J., Hopkins, R. O., Glissmeyer, E. W., Kitterman, N., \& Elliott, C. G. (2006). Cognitive, emotional, and quality of life outcomes in patients with pulmonary arterial hypertension. Respiratory Research. doi: 10.1186/1465-9921-7-55. Health and Prevention of Substance Abuse. (1997). Programme on mental health: WHOQOL measuring quality of life.

World Health Organization. (2001). The world health report 2001, mental health: New understanding, new hope. 1211 Geneva 27, Switzerland.

Zboralski, K., Florkowski, A., BoguszTalarowska, Marian, M., \& Piotr, G. (2008). Quality of life and emotional functioning in selected psychosomatic diseases. Postepy Hig Med Dosw. (Online), 2008(62), 36-41. 